IZA DP No. 5174

Risk Management among the Poor:

The Case of Microfinancial Services

Thankom Arun

Mirko Bendig

September 2010 


\title{
Risk Management among the Poor: The Case of Microfinancial Services
}

\author{
Thankom Arun \\ University of Central Lancashire, \\ University of Manchester and IZA \\ Mirko Bendig \\ University of Göttingen \\ and GIGA

\section{Discussion Paper No. 5174 \\ September 2010} \\ IZA \\ P.O. Box 7240 \\ 53072 Bonn \\ Germany \\ Phone: +49-228-3894-0 \\ Fax: +49-228-3894-180 \\ E-mail: iza@iza.org
}

\begin{abstract}
Any opinions expressed here are those of the author(s) and not those of IZA. Research published in this series may include views on policy, but the institute itself takes no institutional policy positions.

The Institute for the Study of Labor (IZA) in Bonn is a local and virtual international research center and a place of communication between science, politics and business. IZA is an independent nonprofit organization supported by Deutsche Post Foundation. The center is associated with the University of Bonn and offers a stimulating research environment through its international network, workshops and conferences, data service, project support, research visits and doctoral program. IZA engages in (i) original and internationally competitive research in all fields of labor economics, (ii) development of policy concepts, and (iii) dissemination of research results and concepts to the interested public.
\end{abstract}

IZA Discussion Papers often represent preliminary work and are circulated to encourage discussion. Citation of such a paper should account for its provisional character. A revised version may be available directly from the author. 
IZA Discussion Paper No. 5174

September 2010

\section{ABSTRACT}

\section{Risk Management among the Poor: The Case of Microfinancial Services*}

This paper argues that the level of financial services provision determines the risk management strategies among the poor. The paper estimates the determinants of the household's use of one, two or all three types of microfinancial services applying ordered probit models and additionally probit models for combinations of them. By doing this on household survey data from Sri Lanka, there is empirical evidence that household's probability to participate in microfinancial services increases with rising self perception towards risk. Further, we find that it depends highly on the type of risk, if a household is more or less likely to use microfinancial services in Sri Lanka, whereas the accessibility to one, two or three microfinancial services is determined by the experience of specific hazards in the past. The study finds that the poor are less likely to use microfinancial services than their better off counterparts.

JEL Classification: $\quad$ G20, O16, R22

Keywords: $\quad$ financial markets, financial services, microinsurance, Sri Lanka, South Asia

Corresponding author:

Thankom Arun

Lancashire Business School

Faculty of Management

University of Central Lancashire

Preston, Lancashire PR1 2HE

United Kingdom

E-mail: tgarun@uclan.ac.uk

\footnotetext{
* We wish to thank British Academy for the financial support for this research.
} 


\section{Introduction}

In many developing countries, less than half of the population has access to the formal financial markets (World Bank 2008). The lacking access to finance for the majority of population around the world is seen by recent development theorists as a critical instrument for generating persistent income inequality, as well as indicating slower economic growth. The type of risks faced by the poor such as that of death, illness, injury and accident, are no different from those faced by the better off, but the poor are indeed more exposed to such risks that can severely affect their livelihoods due to their economic status, income and earning abilities (Holzmann and Joergensen 2000, Siegel et al. 2001). At two stages, a household can cope with risk, ex ante before a hazard appears to the household or ex post after the occurrence of such shock (Morduch 1995, Morduch 1999, Townsend 1995, Dercon 2002).

In the past financial services were not considered to be an option for low-income groups as an ex ante risk management strategy, as they were seen too poor to afford the costs of financial services such as insurance premiums. Further, they do not seem applicable for formally provided financial services and especially as well as uninsurable to the wide variety of risks they face. Available evidence for developing countries states that households are mostly only partially and not fully insured against income shocks (Morduch 1995, Townsend 1995, Lim and Townsend 1998), so that shocks to household's income such as death of a household member, lead to consumption movements that are not perfectly insurable, and thus may induce famine or death. In such a case financial services can function as risk management strategies serving means to cope with the consequences of a shock and offering savings and insurance products for consumption smoothing as ex ante risk management strategies (Zeller 2001). The availability of sufficient and efficient risk management strategies are widely seen as an important integral to any poverty reduction strategy.

Microfinance may be a way to combat poverty and to develop the institutional capacities of financial systems providing efficiently at first only loans to poor households. In recent years the microfinance movement has become more and more demand-oriented and diversified introducing new product lines, such as savings and insurance products, to low-income groups in developing countries (Zeller and Sharma 2002, Armendáriz and Morduch 2005). Henceforward, a more holistic concept of microfinance is realised not only by microfinance practitioners, but as well among academic circles (Zeller and Sharma 2002, Armendáriz and Morduch 2005). Several contributions exists so far in the literature on the determinants of households' use of financial services of the microfinance sector in developing countries emphasizing one of the financial services, primarily loans, followed by savings and insurance (Muradoglu and Taskin 1996, Jabbar 
et al. 2002, Pal 2002, Asfaw 2003, Jütting 2003, Bhat and Jain 2006, Gine et al. 2008, Swain 2007, Barslund and Tarp 2008). To our knowledge, Bendig et al. 2009 are the first that assume that households' decision for loans, savings products and insurances are highly interconnected and depend on one another for specific causes. Considering this, we capture the diversification of microfinancial service participation of low-income households by estimating the determinants of the usage of no, one, or more than one microfinancial service. By doing so, we emphasize the impact of household's experienced risk exposure as a determinant of household's usage of microfinancial services, which can be used as possible risk management strategies. Further, we assume the more diversified use of microfinancial services in number, such as one, two or all three services, and as well in quality relating to the complexity ${ }^{1}$ of the financial services gives an indication of household's level of financial capability.

Therefore, we first attempt to estimate the determinants, which affect the household's decision to participate in no, only one, two or all three different types of microfinancial services using an ordered probit model. In addition, we calculate probit models on specific combinations of financial services. We focus in particular on the household's self risk assessment and the exposure to different types of severe hazards experienced by the household in the past five years. Thereby, the estimation of an ordered probit model may add additional value by investigating the kind of factors that a household uses more than one financial service and if a higher risk exposure in the past determines the household's decision to diversify and extend the usage of microfinancial services. From this, we attempt to derive which role such services can play in terms of risk mitigation in Sri Lanka. Further, we aim to answer the following questions: (i) What determines the usage of microfinancial services such as loans, savings products, and insurance, offered by microfinance institutions in Sri Lanka? (ii) Who are the households who use these services in Sri Lanka? (iii) Who are the households who use more than one service and who are the households who use no or only one service, i.e. who are the more and who are the less financial capable households?

A comprehensive survey of 330 households conducted in May to July 2008 in Sri Lanka is used in the analysis. Hereby, we focus on the use of financial services, which is determined by the demand and the supply of financial services (World Bank, 2008: 28). By analyzing the usage of microfinancial services, we do not estimate the determinants of demand for microfinancial services, but the determinants of their actual use. This is a mixture of and interrelation between the demand for and supply of financial services in Sri Lanka. Only the households who have

${ }^{1}$ I.e. insurance is widely seen as more complex and so harder to understand than savings products or credits, especially by the poor. 
access to the financial service market can use financial services, so that we implicitly include access into our estimation of the usage of such services ${ }^{2}$.

The outline of the paper is as follows. Following this introduction, section 2 presents the conceptual framework of the study. Section 3 discusses the determinants of the uptake of financial services in developing countries. Section 4 describes the methodologies, including data set, the summary statistics and the estimation methods. Section 5 presents the results. Section 6 concludes.

\section{Conceptual Framework}

The paper argues that financial services function as important risk management and/or risk mitigation strategies, while insurance and savings products are ex ante, i.e. preventive, strategies for consumption smoothing, credit is typically used as an ex post risk management strategy. However, household's decision for loans, savings products and insurances are highly interconnected and depend on one another for specific causes, as users of a financial service have an information advantage due to their membership in a financial institution and a higher level of financial literacy due to their usage of such services than their non-users counterpart (Bendig et al. 2009). Therefore, microfinancial service participation of low-income households, i.e. the usage of no service, one, two or all three types of microfinancial services gives an indication of the diversification of household's financial behavior and respectively the risk management strategies in use.

The study framework structures the relationship between household's participation in financial services and their level of financial capability, and household's abilities to use these as risk management strategies and their vulnerability ${ }^{3}$. Covering a wide range of savings, credit and insurance products, financial services are strategies to address specific financial needs of a household. These services can be provided formally or informally. The participation in financial services is as well determined by household's financial capability level, which are knowledge, skills, experiences and attitudes which make a household more or less capable to manage its money, prepare for risks, plan ahead and respectively use financial services. Financial capability, or financial literacy as it was initially conceived, is a combination of three interrelated elements, i.e. the knowledge, skills and attitudes that make a household capable to manage its finances

\footnotetext{
2 Users of financial services can be distinguished from nonusers. Among the nonusers are those who are excluded by themselves from the use of financial services voluntarily, such as households who do not use financial services due to cultural or religious reasons, and households who do not need or want to use financial services. The other group are the involuntarily excluded households who demand financial services, but do not have access to them in respect to insufficient income or lending risk, discrimination due to social, religious, or ethnic grounds, contractual and informational framework, and too high prices or inappropriate product features offered by the providers (World Bank, 2008: 29).

${ }^{3}$ Vulnerability is defined here as household's risk exposure and their ability to manage such risks, the related consequences, and the microfinancial services participation as measures for managing shocks (Cohen and Sebstad 2003, Matul 2009).
} 
(PFRC 2005, Matul 2009). Financial capability is a relative, not an absolute concept. It may be possible to define a basic level of financial capability, that is required by everyone in a given society. Beyond, the degree and nature of financial capability required by any given individual will be determined by their financial circumstances (PFRC 2005). The knowledge is acquired by experience, education and training; and passively through information from different other sources, e.g. family and friends, media, information meetings organized by or brochures from the microfinance institutions. The state of knowledge will typically increase through a person's life cycle, but however it can become redundant or inaccurate, if circumstances change. The person's knowledge need to be applicable to manage their money and to make appropriate financial decisions. Further, the person must be able to take the necessary steps to apply their knowledge and skills, which depends highly on the attitude towards financial capability. They must be willing to invest the time and other resources to apply their knowledge and skills, able to gain access to information, advice and other resources, and confident enough to exercise their skills and to act on the results.

In behavioral terms ${ }^{4}$, our analysis differentiates between more or less financial capable households (Matul 2009). A more financial capable household is proactive, has a positive attitude towards managing its finance, take longer horizons in financial planning, save systematically, try to insure or at least prepare for risks, and borrow in a responsible way. Further, the household uses differentiated financial services, i.e. more than one service, as risk management strategies, which may lead to higher asset accumulation in the future. A less financial capable household is more reactive, do not see much sense in or is not able to manage money, or plan ahead, and tends to live from hand to mouth and respond spontaneously to risks. The household uses no or less financial services than the more financial capable household. This leads to lower ability to respond to risk they may occur in the future and thus to a higher vulnerability of the household. We analyze who are the more and who are the less financial capable households, i.e. the determining factors of such households. Financial capability is highly related to household's vulnerability (Matul 2009). Siegel et al. (2001) suggest the degree of vulnerability depends on the characteristics of the risk and household's ability to address adequately to the expenditures, which are associated with the consequences of such risks ${ }^{5}$. Vulnerability can be divided into three steps of a risk chain: the incidence of the risk or risky event, the household's decision to choose which type of risk management strategy to respond to the consequences of the peril, and finally what is the outcome, i.e. the welfare loss of the household, of the incidence of the risk (Siegel et al.

\footnotetext{
${ }^{4}$ Four different areas of financial capability are identified, which are money management, planning ahead, risk preparation and usage of financial services (PFRC 2005).

5 'A household can be vulnerable to future loss of welfare below socially accepted norms caused by risky events.' (Siegel et al. 2001: 4)
} 
2001). If the household's welfare decreases after the experience of the shock, household's vulnerability comes explicitly from risks and as well the respective impact of risks shows the degree of household's vulnerability.

\section{Determinants of the Uptake of Financial Services}

We analyze the household's participation in financial services, indicating its financial capability, as a possibility to manage the risks they are faced by. Therefore, it is important to note that in the literature there are several empirical findings on the determinants of the usage of financial services in developing countries, which we use to derive predictions to control for in the estimations. The literature can be divided into three strands analysing each service of the three elements of the finance trinity separately (Bendig et al. 2009). There are considerably more studies discussing especially the issue of credit (Kochar 1997, Atieno 1997, Jabbar et al. 2002, Nguyen et al. 2002, Pal 2002, Pitt and Khandker 2002, Zeller and Sharma 2002, Swain 2007, Barslund and Tarp 2008) than for savings (Gupta 1970, Deaton 1992, Gurgand et al. 1994, Muradoglu and Taskin 1996, Spio and Groenwald 1996, Fafchamps et al. 1998, Kimuyu 1999, Aryeteey and Udry 2000, Kiiza and Pederson 2002, Hoogeven 2003) or insurance in developing countries (Bendig et al. 2009, Asfaw 2003, Cohen et al. 2005, Jütting 2003, Bhat and Jain 2006, McCord et al. 2006, Gine et al. 2008, Gine and Yang 2007). None of these studies estimate the differences between the determinants of household's participation in no, one, two or respectively three microfinancial services. Nevertheless, all studies consider the impact of different determinants, especially several demographic and socioeconomic household characteristics on financial service uptake, from which it is possible to derive propositions for the estimations.

In the literature, female headship is considered to be negatively related to the use of financial services (Pitt and Khandker 2002). Household size is widely recognized as an important determinant of the use of financial services (Dror et al. 2007, Swain 2007, Barslund Tarp 2008). Further, there exist contributions that find a negative relationship between age and the demand for informal credit (Barslund and Tarp 2008) and the demand for insurance (Chankova et al. 2008, Gine et al. 2008). Bendig et al. (2009) find such a life-cycle effect for loans and insurance. Several contributions have found that the household is more likely to take up financial services, especially loans (Kiiza and Pederson 2002, Pal 2002, Pitt and Khandker 2002) or contract insurance with increasing income or wealth of the household (Jütting 2003, Pauly 2004, Bhat and Jain 2006, Dror et al. 2007, Gine et al. 2008). Higher asset endowment and land ownership of a household is expected to have a positive effect on the choice of taking up one or more financial services, whereas lower income earning ability, either self-employed or not employed, are expected to be negatively associated with the use of financial services. If a household receives 
remittances, influence the timing of savings within the life-cycle of a household (Spio and Groenewald 1996). Remittances increase the likelihood for savings products and decreases it for insurance uptake as remittances may function as a insurance substitute (Bendig et al. 2009).

Education has a statistically significant effect either on credit demand (Jabbar et al. 2002, Pitt and Khandker 2002, Swain 2007, Barslund and Tarp 2008), savings (Kiiza and Pederson 2002) or insurance (Chankova et al. 2008, Gine et al. 2008, McCord 2001). Households may differ in their cognitive ability to understand an insurance product and other financial services as well as their willingness to experiment with them. In line with the literature, lower levels of educational attainment may reduce the probability to use any of the three financial services. The positive effect of education is expected to be particularly strong for the use of more than one service or for insurance, as this goes along with higher sophistication of the demand for financial services and a better understanding of such complex engagements.

In developing countries, the uptake of a loan play a significant role for the risk management of a household, as several households use credits not to start a new business activity, but to obtain additional working capital or to restart a business after the experience of a shock (Zeller and Sharma 2002, Nguyen et al. 2002). Further, there exists a positive relation between the household's past exposure of shocks and the usage of microfinancial services differing for the tested risks such as death, illness, or other risks (Bendig et al. 2009). Therefore, we propose that households with a higher exposure to risks have a higher probability to use loans, and a lower probability to use savings and insurance ex post of a shock. Further, we expect a manifold picture related to the type of risks, as the usage of microfinancial services depends highly on the type of risk (Bendig et al. 2009). Further, Gine et al. (2008) find that risk averse low-income households do not have access to insurance. There is evidence that households who feel themselves more exposed to risk are less likely to use financial services (Bendig et al. 2009). It is plausible to suggest that better-off households have a better ability and willingness to bear a given amount of risk compared to relatively poor households, so that the poor are most risk averse, as a given loss can be ruinous for the poor, as they are too close to subsistence in developing countries (Ray 1999). Therefore, we suggest that the use of financial services by lowincome households increases with the degree of risk aversion in Sri Lanka.

\section{Methodology}

\section{a) Sources of Data and Summary Statistics}

The analysis of this paper is based on a household survey conducted from May to July in 2008 in various villages all over Sri Lanka covering all districts and regions. The survey was 
undertaken for a research project on the demand for microinsurance among low-income households in Sri Lanka with a sample size of 330 households, out of which 240 households have bought and 90 have not bought any microinsurance. 209 households have taken up a credit and 200 contracted any savings product in the past five years

In Sri Lanka, the study site covered 30 villages in all 14 districts of all regions. Five different MFIs, namely Women's Development Federation, Women's Development Banking Federation, Sanasa Insurance Company, Yasiru Mutual Fund and SEEDS (Sarvodaya Economic Enterprises Development Services Ltd) had been identified as the main suppliers of voluntary ${ }^{6}$ microinsurance for low-income households in Sri Lanka. The survey sampling frame is a census of households randomly selected from the client bases of the five respective MFIs and allocated among the districts in which the MFIs are operating. From each district, two or three of the respective MFIs have been chosen except from Vavunia and Batticaloa, which are in the Northern and Eastern provinces, where only SEEDS is operating. The selected number of households from each district differs from 15 to 50 households. Two or three villages from each district and one Community Based Organization (CBO) from each village are randomly picked representing the selected MFIs from each district. A total of $30 \mathrm{CBOs}$ are included in the survey with 10 to 15 clients each selected randomly from the client base. Half of these clients are insured and the other half is non-insured. In the case of Yasiru Mutual Fund all clients are insured, so that the non-insured clients were randomly chosen from the non-insured households in the villages, in which the insured clients of the Yasiru Mutual fund are located. In total 330 households were interviewed, including two strata of (micro)insured and non-insured households, whereas 240 households use and 90 do not use any insurance, including insurances offered by other institutions than the five respective MFIs.

The survey questionnaire contained detailed sections on demographic and socioeconomic household characteristics, household assets, the occurrence of shocks, risk management strategies, evaluation of household's risk self assessment and situation. Special focus is given on information about the integration of households in the financial market, i.e. the embedding in different financial institutions, and the use of loans, savings products and in particular insurance. In the estimations the vector of explanatory ${ }^{7}$ variables includes a household's self perception towards risk index as a continuous variable, eight risk exposure dummies, and as control variables different household characteristics including demographic and wealth variables, education,

\footnotetext{
${ }^{6}$ The participating institutions provide credit insurances as well, which are compulsory for the uptake of a loan or other financial product. Yet, these credit insurances are neglected in this analysis and the respective observations are dropped from the data set.

7 Table 7 (in the Appendix) shows the definition and specific details of each variable's construction used as independent variable. All analyses were performed in Intercooled Stata 9.0. To test for potential problems of multicollinearity, we computed the pairwise correlations between the explanatory variables, for the correlation matrix of the explanatory variables, see Table 9 in Appendix. Further, we calculated the variance inflation factors using the collin command in Stata. Except for the regressors "age" and "age squared" all VIFs were less than 2.21. Therefore, we see no reason for concern.
} 
economic activities of the household head and the distance to road as an access to market indicator and information about remittances.

In relation to the dependent variable summary statistics for the sample are presented in Table 1. The descriptive statistics are presented in relation to the categories of the dependent variable used in the estimations of the ordered probit model, namely nonusers of microfinancial services, users of one, two or three microfinancial services.

In order to capture household's attitude towards risk as a proxy for household's degree of risk aversion, we include a variable which covers household's self perception towards risk to a range of risks ${ }^{8}$.

Table 1: Summary Statistics: Use of no, one, two or three microfinancial services

\begin{tabular}{|c|c|c|c|c|c|c|c|c|}
\hline \multirow[t]{2}{*}{ Variable } & \multicolumn{2}{|c|}{ No service } & \multicolumn{2}{|l|}{ One } & \multicolumn{2}{|l|}{ Two } & \multicolumn{2}{|l|}{ Three } \\
\hline & Mean & $\begin{array}{l}\text { Std. } \\
\text { error }\end{array}$ & Mean & $\begin{array}{l}\text { Std. } \\
\text { error }\end{array}$ & Mean & $\begin{array}{l}\text { Std. } \\
\text { error }\end{array}$ & Mean & $\begin{array}{l}\text { Std. } \\
\text { error }\end{array}$ \\
\hline Risk assessment & 0.146 & 0.309 & -0.246 & 0.066 & -0.006 & 0.114 & 0.061 & 0.100 \\
\hline Drought & 0.057 & 0.041 & 0.146 & 0.043 & 0.109 & 0.025 & 0.115 & 0.027 \\
\hline Animal threat & 0.026 & 0.026 & 0.097 & 0.039 & 0.066 & 0.021 & 0.087 & 0.026 \\
\hline Crop Failure & 0.031 & 0.031 & 0.041 & 0.027 & 0.051 & 0.018 & 0.102 & 0.029 \\
\hline Death & - & - & 0.044 & 0.035 & 0.075 & 0.025 & 0.082 & 0.027 \\
\hline Illness & 0.152 & 0.077 & 0.063 & 0.037 & 0.121 & 0.028 & 0.187 & 0.037 \\
\hline Input & 0.094 & 0.444 & 0.197 & 0.049 & 0.095 & 0.024 & 0.275 & 0.044 \\
\hline $\begin{array}{l}\text { No ability to sell } \\
\text { agricultural products }\end{array}$ & - & - & 0.080 & 0.038 & 0.058 & 0.021 & 0.129 & 0.033 \\
\hline Other risk & 0.072 & 0.031 & 0.055 & 0.023 & 0.072 & 0.023 & 0.089 & 0.028 \\
\hline Female head & 0.146 & 0.082 & 0.191 & 0.049 & 0.147 & 0.033 & 0.155 & 0.036 \\
\hline Household size & 3.906 & 0.228 & 3.750 & 0.202 & 4.034 & 0.113 & 4.310 & 0.135 \\
\hline Age & 50.47 & 2.345 & 45.47 & 1.832 & 46.88 & 1.007 & 48.337 & 1.096 \\
\hline Age squared & 2669.1 & 240.95 & 2233.3 & 171.16 & 2317.2 & 98.17 & 2461.9 & 109.51 \\
\hline No or primary education & 0.272 & 0.093 & 0.162 & 0.049 & 0.153 & 0.032 & 0.188 & 0.038 \\
\hline Secondary Education & 0.467 & 0.107 & 0.415 & 0.067 & 0.376 & 0.045 & 0.363 & 0.046 \\
\hline Head is selfemployed & 0.614 & 0.106 & 0.633 & 0.059 & 0.571 & 0.046 & 0.558 & 0.048 \\
\hline Head is unemployed & 0.272 & 0.093 & 0.248 & 0.063 & 0.179 & 0.036 & 0.241 & 0.043 \\
\hline Distance to road & 721.14 & 241.11 & 664.64 & 149.25 & 307.86 & 69.91 & 180.05 & 27.89 \\
\hline Remittance & 0.031 & 0.031 & 0.072 & 0.039 & 0.027 & 0.014 & 0.069 & 0.025 \\
\hline Land Ownership & 0.516 & 0.104 & 0.665 & 0.060 & 0.748 & 0.041 & 0.895 & 0.030 \\
\hline Asset index & -0.863 & 0.125 & 0.053 & 0.129 & -0.069 & 0.092 & 0.353 & 0.088 \\
\hline Observations & 26 & & 67 & & 129 & & 108 & \\
\hline
\end{tabular}

Source: Authors' calculation.

The nonusers of financial services report the highest score of risk assessment, followed by the users of three services, the users of two and one services. Related to the risk exposure experienced by the household in the past five years, we control for eight different dummy variables in our analysis. These variables capture the most severe risks households faced in Sri Lanka in the past five years. In self reported rankings from the survey data the households in Sri Lanka report war and terrorism (19\%) as the most important peril they face in the future; a dramatic increase of input prices (18\%), serious illness of a working adult household member $(8 \%)$ are cited second and third most frequently, followed by drought (8\%). The variable takes

${ }^{8}$ The index is constructed from three questions related to the household's self perception of subjective exposure to health shocks, road or work accidents, and economic shocks compared with neighbouring households and one question about household's own rating of willingness to take risks using factor analysis. We cannot take risk aversion into account in our analysis, as suggested by the literature on insurance demand, since experimental methods used to measure personal risk aversion were not included in our survey and related standardized questions in our survey questionnaire only reflect this in a limited way. 
the value of 1 if a household experienced a severe shock during the previous five years and this had severe ${ }^{9}$ consequences, and 0 otherwise. The dummy variables are if a household experienced a severe drought, animal threat, crop failure, death of a household member, illness of a household member, an increase of input prices, the inability to sell agricultural products, and any other severe shock during the last five years. This category captures mostly idiosyncratic shocks, which may occur beside the hazards already covered by the other seven risk categories. Beside the variables illness of a household member and any other severe shock, a higher share of the users of one, two or three financial services report the incidence of severe shock than the nonusers of financial services.

An asset index ${ }^{10}$ constructed via factor analysis and a dummy variable for land ownership are considered as proxies for the wealth status of a household. Further, we add asset quintile dummies in one estimation to investigate the households who use any financial services in relation to their wealth status. A higher share of the users of one, two or three financial services related to the nonusers of financial services own any land compared to the full sample. The users of three financial services have the highest asset endowment, followed by the users of two and one financial service. The nonusers present the lowest asset endowment score. The users of financial services are generally better off households than the nonusers in the communities surveyed. The data set in general, but especially the demographic and wealth data confirms that the sample consists of poor and middle-income households. The majority of households is engaged in low-income economic activities such as small-scale industrial businesses, petty trading and farm activities at the subsistence level. Around 20 percent of household heads have no formal or only primary education, whereas 40 percent of households heads report that they attained secondary education. Around 60 percent of the household heads are self-employed or contractual workers in either agriculture or non-agricultural activities, whereas around 20 percent of heads are not employed due to young or old age, disability, or similar reasons. The influence of the household size on the usage of financial services depends highly on the composition of the households ${ }^{11}$. Yet, larger households have here a high number of children and elderly people, but as well more economically active adult household members. On average, we find that households who use two or three financial services have more members in their households than nonusers of financial services. The variable age of household head shows that the users of no financial services are significantly older than the users of one, two, or three financial services.

\footnotetext{
${ }_{9}$ Severity is measured in the sense that the household needed more than one month to recover economically from this respective shock.

${ }_{10}$ We controlled if any financial services are used to any asset, such as construction loans. These assets are neglected in the asset index, by doing so, we avoid potential problems of endogeneity. Land is generally not an as easily purchasable assets as other assets, so the influence of endogeneity can be neglected.

11 In our data set, household size correlates highly with the number of dependants (correlation coefficient of 0.79 ) and with the number of children (correlation coefficient of 0.49 ).
} 


\section{b) Estimation Methods}

The usage of the three alternative formal financial services, such as use of savings products, use of loans, and use of insurance, is estimated in the form of an ordered probit model on the alternatives whether or not households used no financial services, only one, two or three financial services in the previous five years. Financial services, which are defined here as formally offered financial services, are services provided by state bank, development bank, domestic private bank, foreign private bank, microfinance institution (MFI), insurance company and financial leasing company. Formal savings products includes all formal financial services, which are voluntarily used for a savings purpose, for instance savings accounts, current accounts or savings plans. ${ }^{12}$ We control for that by excluding all savings products, which were compulsory or bound to any other formal financial service, so that users of formal savings products are only those households which aim for using such products for the genuine purpose of saving or safe storage of money. Formal loans include all loans taken up voluntarily from the mentioned institutions and which are not used for the purchase of any durable assets in the last five years. Formal insurance is confined to those types of insurance which are offered by the microfinance institutions covered by the survey conducted and may be understood as private suppliers. Hence, the category includes mainly health and life insurances, but as well many other types of insurances, such as other life cycle events insurance, vehicle insurance, old age annuities/pension, credit insurance $^{13}$, crop insurance and property insurance, from the respective five different microfinance providing institutions in the sample.

Table 2 and 3 shows that the use for each of these services may be interrelated, as many of the households use several of these services simultaneously. Therefore, we first estimate an ordered probit model with a categorical dependent variable, which has the value 1 for "no financial service", 2 for "one financial service", 3 for "two financial services" and 4 for "all three financial services" and second the determinants of the use of specific combinations of financial services using probit models. The outcomes are here ordered related to the quantity of financial services used by the household. Yet, these quantitative measures indicate important qualitative implications.

\footnotetext{
12 The related question in the survey's questionnaire only mentioned savings and do not ask or distinguish any specific savings products.

13 Credit insurances are not taken into account in this study, as these insurances are mostly not taken up voluntarily, but bounded to any credit or to the allowance of a credit.
} 
Table 2: Use of savings products, loans and/or insurance

\begin{tabular}{l|l}
\hline Use of & $\begin{array}{l}\text { Number of households in } \\
\text { the sample }\end{array}$ \\
\hline None & 26 \\
Savings only & 23 \\
Credit only & 16 \\
Insurance only & 28 \\
Savings and credit & 133 \\
Savings and insurance & 152 \\
Credit and insurance & 168 \\
Savings, credit, and insurance & 108 \\
\hline Total & 330 \\
\hline Source: Authors' illustration
\end{tabular}

Table 3: Use of no, only one, two or three financial services

\begin{tabular}{l|l}
\hline Use of & $\begin{array}{l}\text { Number of households } \\
\text { in the sample }\end{array}$ \\
\hline None & 26 \\
One financial service & 67 \\
Two financial services & 129 \\
Three financial services & 108 \\
\hline Total & 330 \\
\hline Source: Authors' illustration
\end{tabular}

From the first category use of "no financial services" to the latest category use of "all three financial services", not only the quantity, but as well the sophistication and complexity of the use of financial services increases gradually. For this type of dependent variable the ordered probability model is a suitable tool (Greene 2003). The two alternative model types are the ordered logit and the ordered probit model, from which we choose to estimate the ordered probit model, whereas the logit specification is only a trivial modification and appears to make virtually no difference in practice (Greene 2003).

The ordered probit model is built around a latent regression in the same manner as the binomial probit models and based on the following specification:

$$
y^{*}=\beta^{\prime} x+\varepsilon .
$$

Where $\mathrm{x}$ is the vector of explanatory variables set and $\varepsilon$ is the disturbance term. As usual $y^{*}$ is unobserved, but what we do observe is:

$$
\begin{aligned}
& \mathrm{y}=0 \text { if } y^{*} \leq 0, \\
& \mathrm{y}=1 \text { if } 0<y^{*} \leq \mu_{1}, \\
& \mathrm{y}=2 \text { if } \mu_{1}<y^{*} \leq \mu_{2}, \\
& \mathrm{y}=3 \text { if } \mu_{3} \leq y^{*}
\end{aligned}
$$

This is a form of censoring. The $\mu^{\prime} \mathrm{s}$ are unknown parameters to be estimated with $\beta$. The choice of the respondents follows a decision-making process, which depends on certain measurable factors, x, and certain unobservable factors, $\varepsilon$. In the ordered probit model $\varepsilon$ has a standard normal distribution. The probability of observing outcome $\mathrm{i}$ corresponds to the 
probability that the estimated linear function, plus random error, is within the range of the cutpoints estimated the outcome:

$$
\begin{aligned}
& \operatorname{Pr}(y=0)=\Phi\left(\kappa_{0}-\beta^{\prime} x+\mu_{0}\right) \\
& \operatorname{Pr}(y=1)=\Phi\left(\kappa_{1}-\beta^{\prime} x+\mu_{1}\right)-\Phi\left(\kappa_{0}-\beta^{\prime} x+\mu_{0}\right) \\
& \operatorname{Pr}(y=2)=\Phi\left(\kappa_{2}-\beta^{\prime} x+\mu_{2}\right)-\Phi\left(\kappa_{1}-\beta^{\prime} x+\mu_{1}\right) \\
& \operatorname{Pr}(y=3)=1-\Phi\left(\kappa_{3}-\beta^{\prime} x+\mu_{3}\right)
\end{aligned}
$$

$\mu_{j}$ is assumed to be normally distributed in ordered probit. In either case, one estimates the coefficients $\beta_{1}, \beta_{2}, \ldots, \beta_{k}$ together with the cut-points $\kappa_{0}, \kappa_{1}, \kappa_{2}, \kappa_{3}, . \kappa_{0}$ is taken as $-\infty$ and $\kappa_{3}$ is taken as $+\infty$. All of this is a direct generalization of the ordinary two-outcome probit model.

\section{$5 \quad$ Estimation Results and Interpretation}

In Table 4 and 5, we estimate a ordered probit model on the uptake of none, one, two or three financial services ${ }^{14}$. The categorical dependent variable is 1 if a household does not use any financial service, 2 if a household uses one financial service, 3 if a household uses two financial services, or 4 if a household uses three financial services ${ }^{15}$. In Table 5 , we replace in the ordered probit regression the explanatory variable "asset index" with five asset quintiles indicating household's relative wealth status rank in terms of asset endowment to investigate if the poor have access to financial services or if financial service providers successfully target the poor. In comparison, we present for additional value regression estimates of probit models for the use of specific combinations of financial services (Table 6) ${ }^{16}$.

We emphasize household's self risk assessment and exposure to different types of severe hazards experienced by the household in the past five years to analyse the kind of factors determine that a household uses more than one financial service and if a higher risk exposure in the past determines the household's decision to diversify and extend the usage of financial services. From this, we attempt to derive which role such services can play in terms of risk mitigation and financial capability in Sri Lanka. In Table 4 we find that households who perceived themselves more exposed to risk, are more likely to use one, two or three financial

\footnotetext{
${ }_{14}$ Because of the underlying cross-sectional survey data, we treat cautiously any causality of the estimation outcomes due to the inability to control for heterogeneity or potential reverse causal relationships. Further, it is important to note that our findings include potential endogeneity problems, as omitted explanatory or third factor variables influences as well the outcomes and explanations shown here.

15 The coefficients are normalized to reflect the marginal effect of a one-unit change in the explanatory variable on the probability of financial service uptake. We calculated the marginal effects for the ordered probit estimation using the margeff command in Stata (Bartus 2005). Average marginal effects and standard errors for marginal effects are calculated using the delta method.

${ }^{16}$ These findings give an indication what are the determinants of the use of specific combinations of financial services and can be used to add additional value to the discussion of the ordered probit results. The combinations are savings and credit, savings and insurance, credit and insurance, and all three financial services. In addition, we estimate separate probit regressions of the determining factors of the uptake of savings products, loans and insurance (see Table 8 in the Appendix).
} 
services, whereas the latter is statistically not significant. Further, such households are significantly less likely to use no financial service.

Table 4: Ordered probit model on the uptake of financial services (I)

\begin{tabular}{l|llll}
\hline Variable & $\begin{array}{l}\text { No Service } \\
\text { Marginal Effects }\end{array}$ & $\begin{array}{l}\text { One } \\
\text { Marginal Effects }\end{array}$ & $\begin{array}{l}\text { Two } \\
\text { Marginal Effects }\end{array}$ & $\begin{array}{l}\text { Three } \\
\text { Marginal Effects }\end{array}$ \\
\hline $\begin{array}{l}\text { Household's self perception } \\
\text { towards risk }\end{array}$ & $-0.0122^{*}$ & $0.0098^{*}$ & $0.0022^{*}$ & 0.0001 \\
$\begin{array}{l}\text { Drought } \\
\text { Animal threat }\end{array}$ & 0.0132 & -0.0106 & -0.0025 & -0.0001 \\
Crop Failure & -0.005 & 0.0048 & 0.0010 & 0.00005 \\
Death & 0.0151 & -0.0121 & -0.0028 & -0.0002 \\
Illness & $-0.0361^{* * *}$ & $0.0301^{* * *}$ & $0.0058^{* * *}$ & $0.0003^{* *}$ \\
Input & $-0.0387^{* * *}$ & $0.0321^{* * *}$ & $0.0063^{* * *}$ & $0.0003^{* *}$ \\
No ability to sell agricultural & -0.0183 & 0.0151 & 0.0031 & 0.0002 \\
products & $-0.0408^{* * *}$ & $0.0342^{* * *}$ & $0.0063^{* * *}$ & $0.0003^{* *}$ \\
Other risk & & & & \\
Female head & -0.0069 & 0.0057 & 0.0012 & 0.00006 \\
Household size & -0.0047 & 0.0038 & 0.0008 & 0.00004 \\
Age & -0.0044 & 0.0036 & 0.0008 & $0.0004^{*}$ \\
Age squared & -0.0056 & 0.0045 & 0.0010 & 0.00005 \\
No or primary education & 0.00006 & -0.00005 & -0.00001 & -0.0000005 \\
Secondary Education & 0.0049 & -0.0040 & -0.0009 & -0.00005 \\
Head is selfemployed & 0.0008 & -0.0007 & -0.0002 & -0.0000008 \\
Head is unemployed & 0.0159 & -0.0129 & -0.0028 & -0.0001 \\
Distance to road & 0.0162 & -0.0130 & -0.0030 & -0.0002 \\
Remittance & 0.0000009 & -0.0000008 & -0.0000002 & -0.000000009 \\
Land ownership & -0.0205 & 0.0168 & 0.0035 & 0.0002 \\
Asset index & $-0.0598^{* * *}$ & $0.0483^{* * *}$ & $0.0109^{* * *}$ & $0.0006^{* * *}$ \\
\hline Observations & $-0.0318^{* * *}$ & $0.0258^{* * *}$ & $0.0058^{* * *}$ & $0.0003^{* *}$ \\
\hline Source: Authors' calculation & 330 & & & \\
Note: Order & & & & \\
\hline
\end{tabular}

Source: Authors' calculation.

Note: Ordered probit model. Coefficients normalized to display marginal effects. The asterisks indicate level of significance

(Robust z-statistics): ${ }^{* * *}$ significant at 1 percent, ${ }^{* *}$ significant at 5 percent, ${ }^{*}$ significant at 10 percent.

The separate regressions in Table 6 show as well a positive association with household's participation in savings and loans, savings and insurance, loans and insurance, and all three of them. These findings indicate that the uptake of financial services increases with household's self perception towards risk. There is evidence that households may not link financial service uptake with an additional risk, but may see them as measures to cope with the consequences of the risks they face. Household heads take as well combinations of different financial products into consideration due to their financial capability level, when choosing risk management strategies as a reaction of the incidence of a peril. The poor have a higher incentive to secure against the consequences of such hazards and thus, a higher probability to uptake any financial service. This is highly related to the access to financial services, which is often limited for the poor. The explanatory power of our results is constrained due to the perceptive measurement of nature and degree of risk aversion

The experience of specific hazards in the past determines the probability of the uptake for one, two or three financial services (Table 4). The same is true for the estimates for the combinations of financial services in the separate probit model (Table 6). Therefore, we limit our discussion to the statistically significant estimates here. We find that after the experience of the death of a household member households are significantly less likely to use no financial service, 
but more likely to use one, two or three financial services. In contrast to this outcome, we find that the probability to use savings products and credit decreases after the experience of a death in the household. The same outcome appears in the case of severe illness of a household member. After the occurrence of the inability to sell agricultural products in the past five years households have a lower probability to use no service, but a higher probability to use one, two or three financial services. There is no evidence for these three types of risks that an experience of such peril in the past has a negative impact on the household's accessibility to financial services. Overall, it is demonstrated that households uses one or a more diversified pool of financial services as risk management strategies after the experience of certain shocks. The death and severe illness of a household member are both family related and idiosyncratic hazards, which can efficiently covered by respective financial services. It is important to note that such type of risks indicate rather low risk for the providing institutions. The inability to sell agricultural shocks can be an idiosyncratic, but as well an aggregate hazard. It depends highly on the reason for the inability to sell. After the experience of a crop failure or another shock in the past five years household's accessibility to financial services and probability to use all three financial services decreases (Table 6).

Beyond, other characteristics of the household's decision for the use of financial services are included as control variables in the regression ${ }^{17}$. In contrast to earlier contributions in the literature, we find that female headed households are more likely to use one, two, or three financial services compared to their male counterparts, whereas none of the findings is statistically significant. The same holds for the variable household size despite of the outcome for three financial services, which presents a significantly positive association. Further, there is evidence that the probability to uptake savings products and loans, savings products and insurance, loans and insurance, and all three financial products increases with rising household size (Table 6). This indicates that larger households are less likely to have no access to and to use no financial services due to higher incentives for the household heads for protection of the other household members and especially in our case due to the fact that larger households have more economically active adult household members in Sri Lanka.

\footnotetext{
${ }^{17}$ We emphasize the factors with a statistically significant outcome.
} 
Table 5: Ordered probit model on the uptake of financial services (II)

\begin{tabular}{|c|c|c|c|c|}
\hline Variable & $\begin{array}{l}\text { No Service } \\
\text { Marginal Effects }\end{array}$ & $\begin{array}{l}\text { One } \\
\text { Marginal Effects }\end{array}$ & $\begin{array}{l}\text { Two } \\
\text { Marginal Effects }\end{array}$ & $\begin{array}{l}\text { Three } \\
\text { Marginal Effects }\end{array}$ \\
\hline $\begin{array}{l}\text { Household's self perception } \\
\text { towards risk }\end{array}$ & $-0.0288^{* *}$ & $0.0196^{* *}$ & $0.0084 * *$ & 0.0009 \\
\hline Drought & 0.0434 & -0.0286 & -0.0132 & -0.0016 \\
\hline Animal threat & -0.0052 & 0.0035 & 0.0015 & 0.0002 \\
\hline Crop Failure & 0.0249 & -0.0165 & -0.0075 & -0.0009 \\
\hline Death & $-0.0823 * *$ & $0.0591 * *$ & $0.0213^{* * *}$ & $0.0019 * *$ \\
\hline Illness & $-0.0927 * * *$ & $0.0663^{* * *} *$ & $0.0242 * * *$ & $0.0023^{* * *}$ \\
\hline Input & -0.0441 & 0.0307 & 0.0121 & 0.0012 \\
\hline $\begin{array}{l}\text { No ability to sell agricultural } \\
\text { products }\end{array}$ & $-0.1104 * * *$ & $0.0810^{* * *}$ & $0.0271^{* * *}$ & $0.0023^{* * *}$ \\
\hline Other risk & -0.0093 & 0.0063 & 0.0027 & 0.0003 \\
\hline Female head & -0.0000003 & -0.0000002 & 0.00000008 & 0.00000008 \\
\hline Household size & -0.0107 & 0.0073 & 0.0311 & 0.0003 \\
\hline Age & -0.0109 & 0.0074 & 0.0032 & 0.0003 \\
\hline Age squared & 0.0001 & -0.00008 & -0.00004 & -0.0000004 \\
\hline No or primary education & 0.0156 & -0.0105 & -0.0046 & -0.0005 \\
\hline Secondary Education & 0.0059 & -0.0041 & -0.0017 & -0.0002 \\
\hline Head is selfemployed & 0.0307 & -0.0209 & -0.0088 & -0.0009 \\
\hline Head is unemployed & 0.0317 & -0.0212 & -0.0094 & -0.0011 \\
\hline Distance to road & 0.00002 & -0.00001 & -0.0000005 & -0.00000006 \\
\hline Remittance & -0.0509 & 0.0357 & 0.0138 & 0.0013 \\
\hline Land ownership & $-0.1248 * * *$ & $0.0823 * * *$ & $0.0379 * * *$ & $0.0041 * * *$ \\
\hline Quintile 1 & $0.1382 * * *$ & $-0.1155^{* * *}$ & $-0.0597 * *$ & -0.0081 \\
\hline Quintile 2 & $0.1357^{* *}$ & $-0.0875^{* * *}$ & $-0.0429 *$ & -0.0054 \\
\hline Quintile 3 & 0.0122 & -0.0082 & -0.0036 & -0.0004 \\
\hline Quintile 4 & -0.0129 & 0.0088 & 0.0037 & 0.0004 \\
\hline Observations & 330 & & & \\
\hline
\end{tabular}

There is evidence for a life-cycle effect for one, two, and three financial services uptake, whereas none of the estimates is statistically significant (Table 4). Further, age is significantly positive related to the uptake of savings products and credit, but negative related to the uptake of savings products and insurance, insurance and credit, and all three financial services (Table 6). This indicates that with increasing age the household heads are less financial capable to use a more diversified set of financial services than their younger counterparts or are restricted from the access to them. Further, there appears to be a life-cycle effect for the usage of savings products and credit. Household heads with no formal, primary or secondary education are significantly more likely to use no financial services or respectively are excluded from the uptake of financial services than their better educated counterparts, whereas the marginal effects are not statistically significant. Remarkably, we find that household heads with no formal, primary or secondary education are significantly less likely to use a combination of savings products and credit (Table 6). Household's heads lower educational attainment limit their abilities to understand and apply for such services (i.e. a lower financial capability), their perception as possible risk management strategies and as well increase mistrust and risk perception according to the participation in microfinance services and institutions. Further, they might be excluded due to lower income earning abilities and a respective lower socioeconomic status. 
The same outcome for the estimates of the ordered probit regression is true for the selfemployed or unemployed heads. The estimates for the distance to road variable as an financial market access indicator show that households with an increasing distance to the market are more likely to be excluded from the use of financial services, but none of the findings are statistically significant. Remittances increase significantly household's accessibility to financial services and the likelihood to use one, two or more financial services, but none of the estimates is statistically significant. We expect that the household's socioeconomic status is highly related to the participation in financial services in Sri Lanka. There is evidence that households who own any land are significantly less likely to use no financial services and more likely to use one, two, and three financial services.

Households with a higher asset endowment are significantly more likely to use one, two or three financial services (Table 4). Poorer households are more likely to be excluded from the use of financial services than better off households. In Table 6 , there is evidence that the poor have a lower accessibility to use specific combinations of the three financial services. In line with the literature, this indicates that microfinancial services are so far not able to target the poorest households in Sri Lanka adequately or rather the poorest have no or only limited access to such financial services (Hulme and Mosley 1997, Navajas et al. 2002, Datta 2004). In Table 5, we investigate five asset quintiles indicating household's relative wealth status rank in terms of asset endowment to analyze the accessibility to finance for the households in Sri Lank. Households in the two poorest quintiles (Quintile 1 and 2) are significantly more likely to be excluded from the use of financial services, but less likely to use one, two or three financial services compared to the households in the fifth quintile. Households in the third quintile are more likely to have no financial services and less likely to use any financial services and households in the fourth quintile are less likely to use no and more likely to uptake one, two or three financial services, whereas none of these outcomes are statistically significant. We confirm that the accessibility to finance is restricted for the poorest in Sri Lanka. Exclusion can appear voluntarily and involuntarily. However, it is unlikely that the poor choose not to use financial services. Yet, it is probable that they do not use financial services due to religious or cultural reasons or to lower financial capability relating to lacking skills, experience and attitudes for the participation in such schemes. 
Table 6: Probit models on the uptake of financial services

\begin{tabular}{|c|c|c|c|c|}
\hline Variable & $\begin{array}{l}\text { Savings and Loan } \\
\text { Marginal Effects }\end{array}$ & $\begin{array}{l}\text { Savings and } \\
\text { Insurance } \\
\text { Marginal Effects }\end{array}$ & $\begin{array}{l}\text { Loan and } \\
\text { Insurance } \\
\text { Marginal Effects }\end{array}$ & $\begin{array}{l}\text { Savings, Insurance } \\
\text { and Loan } \\
\text { Marginal Effects }\end{array}$ \\
\hline $\begin{array}{l}\text { Household's self perception } \\
\text { towards risk }\end{array}$ & $0.0903^{* *}$ & $0.0012^{* *}$ & $0.0021 * * *$ & $0.0008^{* *}$ \\
\hline Drought & 0.2415 & -0.0007 & -0.0008 & -0.0003 \\
\hline Animal threat & -0.0008 & 0.0003 & -0.0013 & 0.0005 \\
\hline Crop Failure & $0.7625^{* * *}$ & $-0.0012^{* *}$ & -0.0021 & $-0.0010 * *$ \\
\hline Death & $-0.0392 * * *$ & 0.0475 & 0.0623 & 0.0101 \\
\hline Illness & 0.0028 & 0.0016 & 0.0028 & 0.0028 \\
\hline Input & $-0.1848^{* * *}$ & -0.0009 & $-0.0026^{*}$ & -0.0003 \\
\hline $\begin{array}{l}\text { No ability to sell agricultural } \\
\text { products }\end{array}$ & 0.4044 & 0.0206 & 0.0313 & 0.0118 \\
\hline Other risk & $0.3482 *$ & $-0.0015^{* *}$ & $-0.0036 * * *$ & $-0.011 * *$ \\
\hline Female head & 0.1385 & 0.0009 & 0.0040 & 0.0013 \\
\hline Household size & $0.0262 *$ & $0.0011 *$ & $0.0035^{* * *}$ & $0.0008^{*}$ \\
\hline Age & $0.033^{* *}$ & $-0.0009 * *$ & $-0.0014^{*}$ & $-0.0005^{*}$ \\
\hline Age squared & $-0.0003^{* *}$ & $0.0000008^{* *}$ & 0.00001 & $0.0000005^{*}$ \\
\hline No or primary education & $-0.0639 * * *$ & 0.0270 & 0.0626 & 0.0178 \\
\hline Secondary Education & $-0.1077 * *$ & 0.0031 & 0.0049 & 0.0024 \\
\hline Head is selfemployed & $-0.2895^{* *}$ & -0.0003 & 0.0019 & 0.0002 \\
\hline Head is unemployed & $-0.0760 * *$ & -0.0014 & 0.0008 & -0.0009 \\
\hline Distance to road & $0.0001 * *$ & 0.00000006 & 0.00000005 & 0.00000004 \\
\hline Remittance & 0.1025 & 0.0023 & 0.0161 & 0.0043 \\
\hline Land ownership & $0.1353^{* * *}$ & 0.0014 & $0.0028^{*}$ & $0.0013^{*}$ \\
\hline Asset index & $0.0621 * * *$ & $0.0045^{* * *}$ & $0.0087 * * *$ & $0.0033 * * *$ \\
\hline Observations & 133 & 152 & 168 & 108 \\
\hline
\end{tabular}

Source: Authors' calculation.

Note: Ordered probit model. Coefficients normalized to display marginal effects. The asterisks indicate level of significance (Robust z-statistics): ***significant at 1 percent, ** significant at 5 percent, ${ }^{*}$ significant at 10 percent.

Importantly, they might be as well excluded from the use of financial services due to specific requirements of the providers such as too high prices or non-price barriers, contractual or informational framework, discrimination against certain population groups or that they are considered to be unbankable because of lacking or irregular income or too high risk (World Bank 2008). Another reason may be that the poor missing a basic level of financial capability or anybody who understands the services who are available for them, and who is able to fill the respective application forms (World Bank 2008).

\section{Conclusion}

Microfinancial services are promising measures to serve low-income households with different options to use such financial services as risk management or risk mitigation strategies in the case of the experience of severe hazards. They can be both used before or after the incidence of such peril. Important to note is that especially the more diversified participation, i.e. the use of different types of financial services, hold the promise to adequately address the financial needs of the households related to the consequences of certain risks. In this paper, we investigate the determinants for the three different types of financial services by estimating an ordered probit models to analyze the determinants, which affect the household's decision to use no, only one, two or all three different. The estimation procedure allows the following suggestions if 
households identify financial services as possible risk management strategies, whether a past shock experience of a household have an impact on the use of financial services in respect to quantitative and qualitative reasons, and which role such services can play in terms of risk mitigation in Sri Lanka. Thereby, we interpret the estimations result concerning the usage of financial services, i.e. the demand side and the supply side, i.e. the access to financial services, in Sri Lanka.

First, we confirm that the probability to uptake financial services increases with rising household's self perception towards risk. This is true for one, two or three financial services and as well for the specific combinations of the financial products. There is evidence that households may not link financial service uptake with an additional risk, but may see them as diversified measures to cope with the consequences of the risks they face. Combinations of different financial products may play as well a key role as possible, interconnected risk management strategies after the incidence of a shock. The poor have a higher incentive to secure against the consequences of such hazards, but the access to financial services is often limited for them. Therefore, a more developed financial and especially microfinance market in line with a higher geographical outreach and diversity would be necessary to overcome these constraints. Policy makers can set the right legal frameworks and especially incentives for this.

Second, we find that the outcome of the eight dummy variables representing the households' risk exposure in the past five years gives a manifold picture. The accessibility to and the probability of the uptake for one, two or three financial services is determined by the experience of specific hazards in the past. After the experience of the death of a household member households, a severe illness of a household member or an inability to sell agricultural products households in the past five years are significantly more likely to use one, two or three financial services. The death and severe illness of a household member are both family related and idiosyncratic hazards, which can efficiently covered by respective financial services. Remarkably, there is clear evidence that financial services may or are seen as achievable and efficient risk management strategies to mitigate the consequences of an experienced shock or to prevent for possible losses of such hazards in Sri Lanka.

Beyond, we highlight some different and new implications from our estimations for Sri Lanka to add some more value to the discussion on the uptake of financial services in developing countries. First, larger households are less likely to have no access to and more likely to use financial services due to higher incentives for the household heads for protection of the other household members and especially in our case due to the fact that larger households have more economically active adult household members in Sri Lanka. Second, there is a life-cycle effect for the combination of savings products and credit. Third, household heads with no formal, primary 
or secondary education are significantly more likely to be excluded from the uptake of the combination of savings and credit, which indicates a lack of a basic level of financial capability among them. Fourth, the same outcome appears for savings products and credit for the selfemployed or unemployed heads. Finally, better off households are more likely to use financial services than their poorer counterparts in Sri Lanka. Microfinancial services are so far not able to reach the poorest or the accessibility to finance is still limited for the poorest in Sri Lanka. It is unlikely that the poor choose voluntarily not to use financial services due to the high risk exposure they face in the past and in the future. Among the poor, there are some households who neglect to use financial services due to religious or cultural reasons, but the majority of the poor is excluded from finance because of supply-side constraints and their poor understanding of financial markets and products. It is necessary to improve and broaden the access to finance for the poor and to raise the knowledge among low-educated, illiterate and certain religious groups to increase the awareness about the benefits of financial services as adequate and efficient risk management strategies in Sri Lanka. Policy makers have not only to force the development of a better access to finance for the poor, but as well the promotion of household's financial capability levels through increasing the public awareness and implementing financial educational campaigns. From the microfinance sector in Sri Lanka, simple and easily understandable products and the promotion of financial education as well are demanded to empower the poor to use microfinancial services as a diversified set to manage the consequences of risks they are faced by. 


\section{References}

Armendáriz, Beatriz and Jonathan Morduch (2005): The Economics of Microfinance, Chapter 6 Savings and Insurance, Cambridge, Mass. and London: The MIT Press.

Aryeetey, Ernest and Christopher Udry (2000): Saving in Sub-Saharan Africa, CID Working Papers 38, Harvard University: Center for International Development.

Atieno, R. (1997): Determinants of credit demand by smallholder farmers in Kenya: An empirical analysis, in: Tropenlandwirt, 98(1), pp. 63-71.

Asfaw, A. (2003): Cost of Illness, demand for medical care, and the prospect of community health insurance schemes in the rural areas of Ethiopia, Frankfurt: Peter Lang Eds.

Barslund, Mikkel and Finn Tarp (2008): Formal and informal rural credit in four provinces of Vietnam, in: Journal of Development Studies, 44(4), pp. 485-503.

Bartus, Tamás (2005): Estimation of marginal effects using margeff, The Stata Journal 5(3), pp. 309-329.

Bendig, Mirko, Giesbert, Lena and Steiner, Susan (2009): Savings, Credit and Insurance: Household Demand for Formal Financial Services in Rural Ghana, GIGA Working Paper Series, No. 94, January 2009, Hamburg: German Institute of Global and Area Studies.

Bhat, Ramesh and Nishant Jain (2006): Factoring Affecting the Demand for Health Insurance in a Micro Insurance Scheme, Working Paper No. 2006-07-02, Ahmedabad: Indian Institute of Management.

Chankova, Slavea, Sulzbach, Sara and Diop, Francois (2008): Impact of mutual health organizations: evidence from West Africa, Health Policy and Planning, 23(4), pp. 264-276.

Cohen, Monique, Michael McCord and Jennefer Sebstad (2005): Reducing Vulnerability: Demand for and Supply of Micro Insurance in East Africa, in: Journal of International Development 17(3), 319-325.

Cohen, Monique and Jennefer Sebstad (2003): Financial Education for the Poor, Microfinance Opportunities, Working Paper No. 1.

Churchill, Craig (ed.) (2006): Protecting the Poor. A Micro Insurance Compendium, Genf: ILO.

Datta, Dipankar (2004): Microcredit in rural Bangladesh. Is it reaching the poorest?, in: Journal of Microfinance, 6(1), pp. 55-81.

Deaton, Angus (1992): Household Saving in LDCs: Credit Markets, Insurance and Welfare, in: Scandinavian Journal of Economics, 94(2), pp. 253-273.

Dercon, Stefan (2002): Income Risk, Coping Strategies, and Safety Nets, in: World Bank Research Observer, 17(2), pp. 141-166.

Dror, David M., Radermacher, Ralf and Ruth, Koren (2007): Willingness to Pay for Health Insurance Among Rural and Poor Persons: Field Evidence from Seven Micro Health Insurance Units in India, Health Policy, Vol. 82, No. 1. 
Fafchamps, Marcel, Christopher Udry and Katherine Czukas (1998): Drought and saving in West Africa: are livestock a buffer stock?, in: Journal of Development Economics, 55, pp. 273 305.

Gine, Xavier, Robert Townsend und James Vickery (2008): Patterns of Rainfall Insurance Participation in Rural India, The World Bank Economic Review 2008 22(3), pp. 539-566.

Gine, Xavier and Dean Yang (2007): Insurance, credit and technology. Field experimental evidence from Malawi, Policy Research Working Paper 4425, Washington DC: World Bank.

Greene, William H. (2003): Economic analysis, Third edition, Upper Saddle River: Prentice Hall.

Gupta, K.L. (1970): Personal saving in developing nations: Further evidence, in: Economic Record, 46(2), pp. 243-249.

Gurgand, P., G. Pederson and J. Yaron (1994): Outreach and Sustainability of Six Rural Finance Institutions in Sub-Saharan Africa, Discussion Paper No. 248, Washington DC: World Bank.

Holzmann, R. and Jorgensen, S. (1999): Social Risk Management: A New Conceptual Framework for Social Protection, and Beyond, Social Protection Discussion Paper No. 0006, Washington DC: World Bank.

Hoogeveen, Johannes (2003): Evidence on Informal Insurance in Rural Zimbabwe, in: Journal of African Economies 11(2), pp. 249-278.

Hulme, David and Paul Mosley (1997): Finance for the poor of the poorest? Financial innovations, poverty and vulnerability, in: Geoffrey Wood and Iffath Sharif (eds.): Who needs credit? Poverty and finance in Bangladesh, Dhaka: University Press, pp. 96-129.

Jabbar, M.A., S.K. Ehui and R. von Kaufmann (2002): Supply and Demand for Livestock Credit in Sub-Saharan Africa: Lessons for Designing New Credit Schemes, in: World Development, 30(6), pp. 1029-1042.

Jütting, Johannes (2003): Do Community-based Health Insurance Schemes Improve Poor People's Access to Health Care? Evidence From Rural Senegal, in: World Development, 32(2), pp. 273-288.

Kiiza, Barnabas and Glenn Pederson (2002): Household Financial Savings Mobilization: Empirical Evidence from Uganda, in: Journal of African Economies, 10(4), pp. 390-409.

Kimuyu, Peter Kiko (1999): Rotating Saving and Credit Associations in Rural East Africa, in: World Development, 27(7), pp. 1299-1308.

Kochar, Anjini (1997): An empiricalm investigation of rationing constraints in rural credit markets in India, in: Journal of Development Economics, 53(2), pp. 339-371.

Lim, Youngjae and Robert Townsend (1998): General Equilibrium Models of Financial Systems: Theory and Measurement in Village Economies, Review of Economic Dynamics, 1(1): pp. 59118.

Matul, Michal (2009): Financial Behaviours and Vulnerability to Poverty in Low-Income Households in Transition Context, Microinsurance Innovation Facility, Geneva: International Labour Organisation (ILO). 
McCord; Michael J. (2001): Health care microinsurance - case studies from Uganda, Tanzania, India and Cambodia, Small Enterprise Development, 12(1), pp. 25-38.

McCord, Michael J., Gaby Ramm and Elizabeth McGuinness (2006): Microinsurance. Demand and Market Prospects, Study Commissioned by Allianz, GTZ, UNDP.

Morduch, Jonathan (1995): Income Smoothing and Consumption Smoothing, in: Journal of Economic Perspectives, 9(3), pp. 103-114.

Morduch, Jonathan (1999): Between the State and the Market: Can Informal Insurance Patch the Safety Net?, in: World Bank Research Observer, 14(2), pp. 187-207.

Muradoglu, Gulnur and Fatma Taskin (1996): Differences in Household Savings Behaviour: Evidence from Industrial and Developing Countries, in: The Developing Economies, 34(2), pp. 138-153.

Navajas, Sergio et al. (2000) : Microcredit and the poorest of the poor. Theory and evidence from Bolivia, in: World Development, 28(2), pp. 333-346.

Nguyen, Geneviève, Betty Wampfler, Michel Benoit-Cattin and Kimseyinga Savadogo (2002): Characteristics of Household Demand for Financial Services in Highly Uncertain Economies: A Review of Evidence from Burkina Faso, in: Manfred Zeller and Richard L. Meyer (eds.): The Triangle of Microfinance: Financial Sustainability, Outreach, and Impact, Washington DC: Johns Hopkins University Press, pp. 46-68.

Pal, Sarmistha (2002): Household sectoral choice and effective demand for rural credit in India, in: Applied Economics, 14, pp. 1743-1755.

Pauly, M.V. (2004): The demand for health insurance: insights from theory and voluntary markets in less-developed countries, Background paper presented at Wharton Impact Conference on Voluntary Health Insurance in Developing Countries, March 15-16, University of Pennsylvania, http://hc.wharton.upenn.edu/impactconference/index.html (accessed on 07.11.2008).

PFRC (2005): Measuring Financial Capability: An Explanatory Study. Prepared for Financial Services Authority by Personal Finance Research Centre, University of Bristol.

Pitt, Mark M. and Shahidur R. Khandker (2002): Credit programmes for the poor and seasonality in rural Bangladesh, in: Journal of Development Studies, 39(2), pp. 1-24.

Ray, Debraj (1999): Development Economics, Princeton: University Press.

Siegel, P., Alwang, B.J. and Canagarajah, S. (2001): Viewing microinsurance as a social risk management instrument, Social Protection Discussion Paper Series, No. 116, Washington DC: World Bank.

Spio, K. and J.A. Groenewald (1996): Rural Household Savings and the Life Cycle Hypotheses: The Case of South Africa, in: The South African Journal of Economics, 64, pp. 294-304.

Swain, Ranjula Bali (2007): Credit Rationing in Rural India, in: Journal of Economic Development, 27(2), pp. 1-20.

Townsend, Robert (1995): Consumption Insurance: An Evaluation of Risk-Bearing Systems in Low-Income Economies, in: Journal of Economic Perspectives, 9(3), pp. 83-102. 
World Bank (2008): Finance for All? Policies and Piffalls in Expanding Access, World Bank Policy Research Report, Washington DC: World Bank.

Zeller, Manfred (2001): The safety net role of microfinance for income and consumption smoothing, in: Nora Lustig (ed.): Shielding the poor. Social protection in the developing world, Washington DC: Brookings Institution and Inter-American Development Bank, pp. 217-238.

Zeller, Manfred and Manohar Sharma (2002): Access to and Demand for Financial Services by the Rural Poor: A Multicountry Synthesis, in: Manfred Zeller and Richard L. Meyer (eds.): The Triangle of Microfinance: Financial Sustainability, Outreach, and Impact, Baltimore and London: Johns Hopkins University Press, pp. 19-45. 


\section{Appendix}

Table 7: Definition of Explanatory Variables

\begin{tabular}{|c|c|}
\hline Variable & Description \\
\hline $\begin{array}{l}\text { Household's self } \\
\text { perception towards } \\
\text { risk }\end{array}$ & $\begin{array}{l}\text { Household's assessment of risk own risk situation (subjective exposure to health shocks, road or } \\
\text { work accidents, and economic shocks compared with neighbours, own rating of willingness to take } \\
\text { risks), index created by factor analysis }\end{array}$ \\
\hline Drought & $\begin{array}{l}\text { Dummy variable, } 1 \text { if household experienced a drought in the last five years and this shock had } \\
\text { serious consequences, i.e. household needed more than one month to recover, } 0 \text { otherwise }\end{array}$ \\
\hline Animal threat & $\begin{array}{l}\text { Dummy variable, } 1 \text { if household experienced a animal threat in the last five years and this shock } \\
\text { had serious consequences, i.e. household needed more than one month to recover, } 0 \text { otherwise }\end{array}$ \\
\hline Crop failure & $\begin{array}{l}\text { Dummy variable, } 1 \text { if household experienced a crop failure in the last five years and this shock had } \\
\text { serious consequences, i.e. household needed more than one month to recover, } 0 \text { otherwise }\end{array}$ \\
\hline Death & $\begin{array}{l}\text { Dummy variable, } 1 \text { if household experienced the death of a household member in the last five years } \\
\text { and this shock had serious consequences, i.e. household needed more than one month to recover, } 0 \\
\text { otherwise }\end{array}$ \\
\hline Illness & $\begin{array}{l}\text { Dummy variable, } 1 \text { if household experienced the illness of a household member in the last five } \\
\text { years and this shock had serious consequences, i.e. household needed more than one month to } \\
\text { recover, } 0 \text { otherwise }\end{array}$ \\
\hline Input & $\begin{array}{l}\text { Dummy variable, } 1 \text { if household experienced an increase of input prices in the last five years and } \\
\text { this shock had serious consequences, i.e. household needed more than one month to recover, } 0 \\
\text { otherwise }\end{array}$ \\
\hline $\begin{array}{l}\text { No ability to sell } \\
\text { agricultural products }\end{array}$ & $\begin{array}{l}\text { Dummy variable, } 1 \text { if household experienced the shock that the household was not able to sell } \\
\text { agricultural products in the last five years and this shock had serious consequences, i.e. household } \\
\text { needed more than one month to recover, } 0 \text { otherwise }\end{array}$ \\
\hline Other shock & $\begin{array}{l}\text { Dummy variable, } 1 \text { if household experienced a severe shock other than the previous described } \\
\text { shock in the last five years and this shock had serious consequences, i.e. household needed more } \\
\text { than one month to recover, } 0 \text { otherwise }\end{array}$ \\
\hline Household size & Household size \\
\hline Age & Age of the household head \\
\hline Age squared & Age of the household head squared \\
\hline $\begin{array}{l}\text { No or primary } \\
\text { education }\end{array}$ & Dummy variable, 1 if household has no or only primary education, 0 otherwise \\
\hline Secondary education & Dummy variable, 1 if household has secondary education, 0 otherwise \\
\hline Self employed & $\begin{array}{l}\text { Dummy variable, } 1 \text { if household head is self-employed or contractual worker in either agriculture or } \\
\text { non-agricultural activities, } 0 \text { otherwise }\end{array}$ \\
\hline Not employed & $\begin{array}{l}\text { Dummy variable, } 1 \text { if household head is not employed due to young or old age, disability, or similar } \\
\text { reasons, } 0 \text { otherwise }\end{array}$ \\
\hline Head is farmer & Dummy variable, 1 if household head is engaged in any farm activities, 0 otherswise \\
\hline Distance to road & Distance to nearest access road in meter \\
\hline Remittances & $\begin{array}{l}\text { Dummy variable, } 1 \text { if household receives remittances from former household members who have } \\
\text { migrated, } 0 \text { otherwise }\end{array}$ \\
\hline Land & Dummy variable, if the household owns any land, 0 otherwise \\
\hline Assets & Assets index \\
\hline Quintiles 1 - 5 & $\begin{array}{l}\text { Five asset index quintiles labeled as Quintile } 1 \text { to } 5 \text {, Quintile } 1 \text { is the poorest quintile and Quintile } 5 \\
\text { is the quintile of households with the highest asset endowment. } \\
\text { Dummy variables, } 1 \text { if household belong to the asset index quintile, } 0 \text { otherwise. (Quintile } 5 \\
\text { functions as reference category) }\end{array}$ \\
\hline
\end{tabular}

Source: Authors' illustration. 
Table 8: Outcome of separate probit models for the use of financial services

\begin{tabular}{l|lll}
\hline Variable & $\begin{array}{l}\text { Use of Savings } \\
\text { Marginal Effects }\end{array}$ & $\begin{array}{l}\text { Use of Loans } \\
\text { Marginal Effects }\end{array}$ & $\begin{array}{l}\text { Use of insurance } \\
\text { Marginal Effects }\end{array}$ \\
\hline $\begin{array}{l}\text { Household's self perception } \\
\text { towards risk }\end{array}$ & $0.323^{* * *}$ & $0.614^{* * *}$ & $0.003^{* * *}$ \\
Drought & $-0.773^{* * *}$ & 0.107 & -0.001 \\
Animal threat & $0.518^{* * *}$ & 0.151 & -0.001 \\
Crop Failure & 0.190 & $0.722^{* * *}$ & $-0.003^{* *}$ \\
Death & $0.409^{* * *}$ & $-0.360^{* * *}$ & 0.217 \\
Illness & $0.451^{* * *}$ & -0.232 & 0.0001 \\
Input & $-0.946^{* * *}$ & $-0.404^{* * *}$ & $-0.003^{*}$ \\
No ability to sell agricultural & $0.414^{* * *}$ & $0.702^{* * *}$ & 0.019 \\
products & & & $-0.004^{* * *}$ \\
Other risk & 0.104 & $0.763^{* * *}$ & 0.009 \\
Female head & 0.278 & $0.881^{* * *}$ & $0.004^{* * *}$ \\
Household size & -0.106 & $0.147^{* * *}$ & $-0.002^{* * *}$ \\
Age & 0.131 & $0.214^{* * *}$ & $0.00002^{* *}$ \\
Age squared & $-0.002^{*}$ & $-0.002^{* * *}$ & 0.123 \\
No or primary education & $-0.821^{* * *}$ & $-0.492^{* * *}$ & $0.009^{*}$ \\
Secondary Education & $-0.725^{* * *}$ & $-0.239^{*}$ & 0.002 \\
Head is selfemployed & 0.392 & $-0.970^{* * *}$ & 0.0003 \\
Head is unemployed & $0.627^{* * *}$ & $-0.649^{* * *}$ & 0.000002 \\
Distance to road & -0.0004 & $0.0008^{* * *}$ & 0.048 \\
Remittance & $-0.639^{* * *}$ & $0.569^{* *}$ & 0.003 \\
Land ownership & $0.947^{* * *}$ & $0.392^{* * *}$ & $0.012^{* * *}$ \\
Asset index & 0.221 & $0.309^{* * *}$ & 330 \\
\hline Observations & 330 & 330 & \\
\hline Source: Auho & & & \\
\hline
\end{tabular}

Source: Authors' calculation.

Note: Probit models. Coefficients normalized to display marginal effects. The asterisks indicate level of significance (Robust zstatistics): ${ }^{* * *}$ significant at 1 percent, ${ }^{* *}$ significant at 5 percent, ${ }^{*}$ significant at 10 percent. 
Table 9: Correlation matrix of explanatory variables

\begin{tabular}{|c|c|c|c|c|c|c|c|c|c|c|c|c|c|c|c|c|c|c|c|c|c|}
\hline Variables & \begin{tabular}{l|} 
Risk \\
Assessment
\end{tabular} & Drought & $\begin{array}{l}\text { Animal } \\
\text { Threat }\end{array}$ & \begin{tabular}{|l} 
Crop Failure \\
\end{tabular} & Death & Illness & Input & $\begin{array}{l}\begin{array}{l}\text { Agricultural } \\
\text { Products }\end{array} \\
\end{array}$ & $\begin{array}{l}\text { Other } \\
\text { shock }\end{array}$ & $\begin{array}{l}\begin{array}{l}\text { Female } \\
\text { head }\end{array} \\
\end{array}$ & \begin{tabular}{|l|}
$\begin{array}{l}\text { Household } \\
\text { size }\end{array}$ \\
\end{tabular} & Age & $\begin{array}{l}\begin{array}{l}\text { Age } \\
\text { squared }\end{array} \\
\end{array}$ & $\begin{array}{l}\text { No or } \\
\text { primary }\end{array}$ & Secondary & $\begin{array}{l}\text { Self } \\
\text { employed }\end{array}$ & \begin{tabular}{l|} 
Not \\
employed
\end{tabular} & \begin{tabular}{|l|} 
Distance \\
\end{tabular} & \begin{tabular}{l|} 
Remittance \\
\end{tabular} & Land & Assets \\
\hline $\begin{array}{l}\text { Risk } \\
\text { assessment }\end{array}$ & 1.00 & & & & & & & & & & & & & & & & & & & & \\
\hline Drought & -0.03 & 1.00 & & & & & & & & & & & & & & & & & & & \\
\hline Animal Threat & 0.05 & \begin{tabular}{|l|}
0.47 \\
\end{tabular} & 1.00 & & & & & & & & & & & & & & & & & & \\
\hline Crop Failure & 0.06 & \begin{tabular}{|l|l|}
0.14 \\
\end{tabular} & 0.17 & 1.00 & & & & & & & & & & & & & & & & & \\
\hline Death & 0.02 & \begin{tabular}{|l|}
-0.03 \\
\end{tabular} & -0.04 & 0.05 & 1.00 & & & & & & & & & & & & & & & & \\
\hline Illness & 0.09 & -0.02 & -0.03 & 0.08 & -0.0 & 1.00 & & & & & & & & & & & & & & & \\
\hline Input & -0.01 & 0.22 & 0.23 & \begin{tabular}{|l|}
0.19 \\
\end{tabular} & -0.04 & -0.01 & 1.00 & & & & & & & & & & & & & & \\
\hline $\begin{array}{l}\text { Agricultural } \\
\text { products }\end{array}$ & -0.03 & 0.49 & 0.28 & 0.21 & -0.04 & 0.01 & 0.33 & 1.00 & & & & & & & & & & & & & \\
\hline Other shock & 0.01 & -0.12 & -0.09 & -0.09 & -0.09 & -0.13 & -0.15 & -0.09 & 1.00 & & & & & & & & & & & & \\
\hline Female head & -0.01 & 0.06 & 0.10 & \begin{tabular}{|l|}
0.02 \\
\end{tabular} & 0.18 & -0.09 & 0.06 & -0.01 & 0.04 & 1.00 & & & & & & & & & & & \\
\hline $\begin{array}{l}\text { Household } \\
\text { size }\end{array}$ & 0.04 & \begin{tabular}{|l|l|}
-0.04 \\
\end{tabular} & -0.05 & \begin{tabular}{|l|}
0.11 \\
\end{tabular} & 0.01 & 0.13 & 0.04 & 0.06 & 0.10 & -0.25 & 1.00 & & & & & & & & & & \\
\hline Age & 0.15 & \begin{tabular}{|l|}
-0.02 \\
\end{tabular} & 0.03 & \begin{tabular}{|l|}
0.00 \\
\end{tabular} & 0.02 & 0.10 & 0.03 & -0.01 & $\begin{array}{l}-0.08 \\
\end{array}$ & 0.17 & 0.0975 & 1.00 & & & & & & & & & \\
\hline Age squared & 0.17 & \begin{tabular}{|l|}
-0.02 \\
\end{tabular} & 0.02 & \begin{tabular}{|l|}
0.02 \\
\end{tabular} & 0.03 & 0.11 & 0.03 & -0.02 & -0.07 & 0.16 & \begin{tabular}{|l|}
0.08 \\
\end{tabular} & 0.98 & 1.00 & & & & & & & & \\
\hline No or primary & 0.17 & 0.01 & 0.02 & \begin{tabular}{|l|l|}
0.07 \\
\end{tabular} & 0.07 & \begin{tabular}{|l|l|}
0.07 \\
\end{tabular} & -0.01 & 0.06 & 0.02 & 0.13 & 0.15 & 0.36 & 0.37 & 1.00 & & & & & & & \\
\hline SSSecondary & -0.08 & \begin{tabular}{|l|}
0.00 \\
\end{tabular} & -0.00 & \begin{tabular}{|l|}
0.02 \\
\end{tabular} & -0.07 & $\begin{array}{ll}0.07 \\
\end{array}$ & 0.02 & 0.03 & -0.00 & -0.02 & \begin{tabular}{|l|}
0.00 \\
\end{tabular} & -0.01 & -0.03 & -0.40 & 1.00 & & & & & & \\
\hline Self employed & -0.03 & \begin{tabular}{|l|}
0.19 \\
\end{tabular} & 0.11 & \begin{tabular}{|l|l|}
0.05 \\
\end{tabular} & 0.02 & 0.02 & 0.04 & 0.15 & 0.02 & -0.04 & 0.05 & -0.11 & -0.13 & 0.04 & 0.04 & 1.00 & & & & & \\
\hline Not employed & 0.09 & \begin{tabular}{|l|}
-0.13 \\
\end{tabular} & -0.05 & -0.01 & 0.02 & 0.05 & -0.01 & -0.08 & 0.05 & 0.19 & -0.01 & 0.34 & 0.37 & 0.17 & -0.03 & -0.65 & 1.00 & & & & \\
\hline Distance & -0.02 & \begin{tabular}{|l|}
-0.04 \\
\end{tabular} & -0.09 & \begin{tabular}{|c|}
-0.09 \\
\end{tabular} & 0.05 & -0.05 & -0.09 & -0.01 & -0.00 & -0.03 & -0.16 & -0.13 & -0.12 & 0.01 & -0.08 & 0.17 & -0.10 & \begin{tabular}{|l|}
1.00 \\
\end{tabular} & & & \\
\hline Remittance & -0.06 & \begin{tabular}{|c|}
-0.00 \\
\end{tabular} & 0.13 & \begin{tabular}{|l|}
0.09 \\
\end{tabular} & -0.01 & 0.02 & 0.10 & -0.02 & -0.03 & 0.22 & -0.03 & 0.18 & 0.19 & 0.17 & -0.08 & -0.03 & 0.11 & -0.04 & 1.00 & & \\
\hline Land & 0.03 & \begin{tabular}{|l|l|}
0.19 \\
\end{tabular} & 0.08 & \begin{tabular}{|l|l|}
0.13 \\
\end{tabular} & 0.07 & -0.03 & 0.16 & 0.16 & 0.06 & 0.03 & \begin{tabular}{|l|l|}
0.08 \\
\end{tabular} & 0.06 & 0.06 & 0.04 & -0.15 & -0.05 & 0.028 & -0.30 & 0.02 & 1.00 & \\
\hline Assets & -0.12 & \begin{tabular}{|l|l}
-0.18 \\
\end{tabular} & -0.14 & \begin{tabular}{|l|l|}
0.14 \\
\end{tabular} & -0.03 & -0.03 & 0.08 & -0.01 & -0.01 & -0.11 & \begin{tabular}{|l|l|}
0.11 \\
\end{tabular} & -0.03 & -0.03 & -0.19 & -0.11 & -0.11 & -0.03 & -0.14 & 0.02 & \begin{tabular}{|l|l}
0.07 \\
\end{tabular} & $\begin{array}{l}1.00 \\
\end{array}$ \\
\hline
\end{tabular}

